\title{
Traces of entrepreneurship in the artistic context
}

LISA BALZARIN

lisa.balzarin@unive.it

Department of Management, $\mathrm{Ca}^{\prime}$ Foscari University of Venice

Monica Calcagno

calc@unive.it

Department of Management, $\mathrm{Ca}^{\prime}$ Foscari University of Venice

The interplay between the world of arts and that of business is at the centre of the present work, where the processes of artistic entrepreneurship are investigated through the observation of a group of artists living the experience of founding their own cultural enterprises in the context of performing arts.

Attracted by key words such as creativity and innovation (Sarri, Bakouros and Petridou, 2010), that such a great importance have in both the artistic (Hagoort, 2004; Nyström, 2006; Louden, 2013) and the entrepreneurial experience, management studies are focused on the in- 
vestigation of the processes through which innovative and creative ideas are turned into entrepreneurial experiences in the art world (Scherdin and Zander, 2011). Consequently, the observation of the artistic process (Peterson and Berger, 1997) became a consolidated field of research, in combination with the study of those capabilities supporting the artist in a complex set of activities addressed to support the creative idea (Scherdin and Zander, 2011).

In this perspective, the artist-entrepreneur (Caplin, 1980; Calcagno, 2013) is the pivot of a process, whose strategic relevance is reinforced by the chronicle absence of public funds pushing a growing number of artists to experience the role of entrepreneur (Scherdin and Zander, 2011). The question is then twofold: who are these professionals? How do they behave making sense of the processes through which artistic and entrepreneurial acts merge?

Adopting a qualitative method of research (Meyers, 2009a 2013b; Yin, 1989a, 2014b), the research aims to analyse the experience of a number of artists living this hybrid professional condition. More specifically, the paper analyses the 
context of live performing arts (circus, dance, theatre).

At first, seventeen semi-structured interviews were conducted. The identified professionals were both artists-entrepreneurs and "not-artistic" professionals (cultural managers and specialised accountants in cultural sector) involved in the entrepreneurial performing arts world and directly working with artists-entrepreneurs. Secondly, data have been discussed and triangulated by the authors identifying emerging practices and key words used by the artists-entrepreneurs, and interpreting the meanings attributed to some shared practices. Finally, four case studies were identified to conduct an in-depth investigation. The selection has been driven by the principles of geographic commonality, complexity and completeness, and diversification of entrepreneurial strategies and conceptions.

The result is a picture of what the contemporary artists-entrepreneurs are: they act entrepreneurially guided by the respect of the integrity of the Art and assume the role of gatekeepers of the quality of their product, 


\section{puntOorg}

challenging logics and structures of the business world.

\section{Keywords}

artist, cultural entrepreneurship, integrity

\section{References List}

Sarri, K.K, Bakouros, I.L., Petridou, E. (2010) “Entrepreneur training for creativity and innovation", Journal of European Industrial Training, 34(3): 270288.

Hagoort, G. (2004) Art management: entrepreneurial style, Delft: Eburon Publishers.

Nyström H. (2006) "Creativity and Entrepreneurship", Creativity and Innovation Management, 2(4): 237-242.

Louden, S. (2013) Living and sustaining a creative life, Intellect.

Scherdin, M., Zander, I. (2011) Art Entrepreneurship, London: Edward Elgar.

Calcagno, M. (2013) Narrare terre di mezzo. Management arte design, Naples: Editoriale Scientifica.

Caplin, L. (1980) "A portrait of an artist as an entrepreneur", Performing Arts Review, 10(4): 433-442. 
Myers, M. D. (2009) Qualitative Research in Business \& Management, London: Sage.

Myers, M. D. (2013) 2nd edition Qualitative research in business and management, London: Sage.

Yin, R.K. (1989) Case study research: design and methods. Applied Social Research Methods Series, Vol. 5, USA: Sage.

Yin, R.K. (2014) 5th edition Case study research: design and methods. Applied Social Research Methods Series, USA: Sage.

PIJ/Volume 1 - Issue 2/2016 - 55 - 